\title{
A RELATION BETWEEN HEMODYNAMIC AND PLASMA VOLUME ALTERATIONS DURING GENERAL ANESTHESIA IN MAN ${ }^{1}$
}

\author{
By HENRY L. PRICE, MARTIN HELRICH,2 AND EUGENE H. CONNER \\ (From the Departments of Anesthesiology, Hospital of the University of Pennsylvania, the \\ Philadelphia General Hospital, and the Harrison Department of Surgical Research, \\ University of Pennsylvania School of Medicine, Philadelphia, Pa.)
}

(Submitted for publication July 22, 1955; accepted September 28, 1955)

Measurements made in man during surgical operations and ether anesthesia have shown that a reduction in blood volume occurs which is too great to be explained by external blood loss $(1,2)$. On the basis of plasma volume and thiocyanate space estimations, it appears likely that the unexplained part of the change in blood volume results from a loss of plasma water to extracellular fluid (2).

Among the possible causes for such a fluid shift, the most likely is a disparity between capillary filtration and reabsorption, and lymphatic return, produced in turn by changes in the level of blood pressure. The hemodynamic alterations produced by general anesthesia may therefore be of prime importance in determining the net loss or gain of plasma water from the capillary blood. However, hemodynamic measurements have usually not been made during anesthesia in conjunction with blood volume determinations. Further, it has not been sufficiently appreciated that different anesthetic agents produce characteristic circulatory changes which could explain differences in their effects on the plasma volume.

Animal studies have suggested that part of the change in circulating blood volume during anesthesia is attributable to the release or storage of erythrocytes by the spleen (3-6). Changes in the blood volume during anesthesia in man have sometimes been similarly explained, although the importance of splenic dilatation or contraction in producing blood volume changes has yet to be demonstrated in this species.

The present study reports the changes in blood and plasma volume observed during cyclopropane, ether, and thiopental anesthesia in thirty-one healthy patients scheduled for elective operations.

1 Supported (in part) by grant H-1568 from the United States Public Health Service.

2 Postdoctorate Fellow of the National Heart Institute.
Blood volume determinations were made using the dye $\mathrm{T}-1824$ or the isotope $\mathrm{Cr}^{51}$; in addition, arterial and peripheral venous pressures were continuously measured before, during, and after anesthesia and operation.

\section{PROCEDURE}

Thirty-one hospital patients scheduled for minor elective operations were studied. The age range was from 23 to 76 years. Different anesthetics were alternated to reduce the influence of seasonal changes.

Procedure $A$. In ten subjects blood samples were withdrawn into oxalated tubes from the brachial artery before and after the intravenous injection of 15 to $20 \mathrm{mg}$. $\mathrm{T}-1824$. The disappearance rate of dye from the plasma was estimated from the plasma concentration in blood samples drawn from the brachial artery ten, twenty, thirty, and forty minutes following the injection of dye. The optical densities of the plasma samples were plotted against time on semilogarithmic graph paper and extrapolated to determine the changes in plasma volume occurring after drug administration. Hematocrits were read in quadruplicate on all blood samples and the plasma volume changes were calculated from these measurements as well.

Procedure $B$. In twenty-one subjects blood was withdrawn from four to fourteen hours prior to the scheduled time of operation and labelled with $\mathrm{Cr}^{\mathrm{si}}$ according to the method of Gray and Sterling (7). The suspension of tagged cells was injected intravenously into the subject at least one-half hour before the study began. The period of study was from two hours pre-operatively until one or two hours post-operatively.

Pre-anesthetic sedation consisted either of atropine sulfate or scopolamine hydrobromide ( 0.4 to $0.6 \mathrm{mg}$. I.V.) in five subjects, while in the remaining sixteen cases morphine sulfate (10 mg. I.V.) was later given.

Anesthesia was induced and maintaind with cyclopropane-oxygen in ten subjects, using a closed system with carbon dioxide absorption. Ether anesthesia was induced with a mixture of nitrous oxide, oxygen and ether and maintained with oxygen-ether in five subjects. In the remaining cases thiopental sodium, supplemented with nitrous oxide-oxygen provided anesthesia. The period between the induction of anesthesia and the beginning of operation ranged from forty-five to eighty minutes. 


\section{METHODS}

Blood samples were drawn from the brachial artery. Those for gas analysis were collected in syringes moistened with heparin; those for counting into oxalated tubes. The blood loss from sampling and operation was approximately one hundred milliliters. This loss was not replaced. Correction for the radioactivity lost by hemorrhage affected the results negligibly.

For the determination of plasma T-1824 concentration the optical density of plasma was read at $622.5 \mathrm{~m} \mu$ against blank plasma. Hematocrits were determined in capped Wintrobe tubes spun at $2300 \mathrm{~g}$. (at the tip) for thirty minutes. The factor 0.98 was applied to correct for trapped plasma (8). Hemoglobin concentration was calculated from the optical density of oxyhemoglobin at $540 \mathrm{~m} \mu$. The ratio between counts per minute and hemoglobin concentration was constant within the limits of experimental error in all samples drawn from the same subject; this was also true of the ratio between counts per minute and the peripheral hematocrit. The standard deviation of duplicate counts was \pm 0.51 per cent.

The $\mathrm{pH}$ of blood samples was determined in a glass electrode at room temperature and corrected to $37^{\circ} \mathrm{C}$ (9). Nitrous oxide and cyclopropane in blood were determined manometrically by the method of Orcutt and Waters (10), diethyl ether by a modification of the method of Shaffer and Ronzoni (11), and thiopental by the method of Brodie and his co-workers (12). Oxygen and carbon dioxide were determined in a van Slyke manometric gas analysis apparatus, and the $\mathrm{pCO}_{2}$ was read from a nomogram (13). Samples containing diethyl ether were analyzed for carbon dioxide using the modification suggested by Austin (14).

The red cell volume was calculated as $\mathrm{RCV}=$ (total counts injected/counts per $\mathrm{ml}$. of blood after circulatory mixing) $\times$ corrected peripheral hematocrit. Total blood volume could be estimated as $B V=\frac{R C V}{0.9 \times \text { Hct. }}$, utilizing the value for the whole body-peripheral hematocrit ratio determined by Gibson, Peacock, Seligman, and Sack (15), Chaplin, Mollison, and Vetter (16), and Strumia and his co-workers (17). Similarly, plasma volume change was calculated from the peripheral hematocrit using the formula $\mathrm{PV}_{\mathrm{t}} / \mathrm{PV}_{0}=\left(\frac{1}{0.9 \mathrm{H}_{\mathrm{t}}}-1\right) /\left(\frac{1}{0.9 \mathrm{H}_{0}}-1\right)$, where the subscripts refer to the quantities measured at different times. The ratio of plasma volumes calculated by dye dilution is $\mathrm{PV}_{\mathrm{t}} / \mathrm{PV}_{0}=\mathrm{OD}_{0} / \mathrm{OD}_{\mathrm{t}}$, where $\mathrm{OD}_{0}$ is the optical density expected (from the extrapolated line) at time $t$, and $O D_{t}$ is the value observed at this time.

Arterial pressure was measured from the brachial artery, and venous pressure from an antecubital vein using Lilly capacitance manometers.

\section{RESULTS}

I. Comparison of plasma volume changes measured with tagged plasma protein and erythrocytes

The calculation of plasma volume changes from the dilution of tagged red cells requires the assumption that the ratio of whole body to peripheral hematocrit remains constant under the condition studied. It is not known whether anesthesia alters this ratio in man; therefore it was considered advisable to compare the plasma volume changes determined simultaneously from the peripheral hematocrit and the plasma protein concentration measured with T-1824.

The plasma volume changes calculated by the two methods agreed satisfactorily up to eighty or ninety minutes after the injection of $\mathrm{T}-1824$, and the values obtained during this interval in ten subjects have been summarized in Table I. After approximately ninety minutes the plasma volume changes measured by dye dilution usually exceeded those calculated from the hematocrit whenever the plasma volume was diminished during anesthesia; the converse was generally true when the plasma volume increased.

\section{Plasma volume changes as related to those in arterial and venous pressures during anes- thesia and operation}

Changes in plasma volume and arterial and venous pressures occurring after pre-anesthetic se-

TABLE I

Plasma volume changes associated with the administration of morphine and anesthetic agents

\begin{tabular}{|c|c|c|c|c|c|c|}
\hline \multirow{3}{*}{$\begin{array}{l}\text { Pre-anesthetic } \\
\text { medication or } \\
\text { anesthetic agent }\end{array}$} & \multicolumn{4}{|c|}{ Change in plasma volume (per cent) } & \multirow{3}{*}{$\begin{array}{l}\text { Difference } \\
\quad \pm \text { S. E. }\end{array}$} & \multirow{3}{*}{$\begin{array}{c}\text { Number } \\
\text { of obser } \\
\text { vations }\end{array}$} \\
\hline & \multicolumn{2}{|c|}{ Calculated from het. } & \multicolumn{2}{|c|}{ From $T-1824$ concentration } & & \\
\hline & Average & Range & Average & Range & & \\
\hline Morphine & +4.8 & 0 to +16.0 & +5.4 & +0.5 to +21.2 & $-0.6 \pm 1.24$ & 5 \\
\hline Cyclopropane & -10.5 & -5.2 to -18.4 & -11.8 & -5.1 to -24.6 & $+1.3 \pm 1.25$ & 10 \\
\hline Diethyl ether & -5.8 & -2.8 to -7.7 & -6.8 & -4.2 to -9.3 & $+1.0 \pm 0.55$ & 6 \\
\hline Thiopental & +3.4 & $1.6+$ to +5.0 & +2.9 & 0 to +6.1 & $+0.5 \pm 0.95$ & 5 \\
\hline
\end{tabular}


Table II

EFFECTS OF SEDATION AND ANESTHESU ON PLABMA VOLUNE AND ARTERLL AND VENOUS PRESBURES

\begin{tabular}{|c|c|c|c|c|c|c|c|}
\hline Drus & $\begin{array}{l}\text { Amt. or Blood } \\
\text { Concentration }\end{array}$ & $\begin{array}{c}\text { Average Change } \\
\text { in Mean A.P. }\end{array}$ & $\begin{array}{c}\text { Average Change } \\
\text { in V.P. }\end{array}$ & $\begin{array}{c}\text { Change in } \\
\text { P. V. \& }\end{array}$ & $\begin{array}{l}\text { Change in } \\
\text { P. V. ml. }\end{array}$ & $\begin{array}{l}\text { Sub- } \\
\text { jects }\end{array}$ & $\begin{array}{l}\text { Obser- } \\
\text { vations }\end{array}$ \\
\hline $\begin{array}{l}\text { Atropine } \mathrm{SO}_{4} \\
\text { or } \\
\text { ecopolnmine } \mathrm{HB}_{\mathbf{r}}\end{array}$ & $0.4-0.6 \mathrm{mg}, 1 . v$. & $+3 \mathrm{~mm} . \mathrm{Hg}$ & $\cdots$ & $\begin{array}{l}M+1.7 \\
R-1.1 \text { to }+6.8\end{array}$ & $\begin{array}{l}M+55 \\
R-30 \text { to }+210\end{array}$ & 5 & 12 \\
\hline $\begin{array}{l}\text { As above, plus } \\
\text { morphine } \mathrm{SO}_{4}\end{array}$ & $10 \mathrm{mg} .1 . \mathrm{v}$. & $-4 \mathrm{~mm} . \mathrm{Hg}^{* *}$ & - & $\begin{array}{l}M+6.0 \\
R-1.0 \text { to }+20.9\end{array}$ & $\begin{array}{l}M+166 \\
R-30 \text { to }+525\end{array}$ & 16 & 26 \\
\hline $\begin{array}{l}\text { Cyclopropene } \\
\text { (Ifat) }\end{array}$ & 6. 1-12 mg. $\%$ & $+3 m m . ~ H s$ & $+7.9 \mathrm{~cm} . \mathrm{H}_{2} \mathrm{O}^{*}$ & $\begin{array}{l}M+1.4 \\
R-6.1 \text { to }+11.6\end{array}$ & $\begin{array}{l}M+40 \\
R-150 \text { to }+180\end{array}$ & 5 & 14. \\
\hline $\begin{array}{l}\text { Cyclopropene } \\
\text { (doep) }\end{array}$ & $17-26$ mg. 8 & $+20 \mathrm{~mm} . \mathrm{Hg}^{*}$ & $+14.2 \mathrm{~cm} . \mathrm{H}_{2} \mathrm{O}$ & $\begin{array}{l}\mathbf{M}-8.8 * \\
\mathbf{R}-6.2 \text { to }-17.3\end{array}$ & $\begin{array}{l}M-312 . \\
R-150 \text { to }-420\end{array}$ & 5 & 11 \\
\hline $\begin{array}{l}\text { Dlothyl other } \\
\text { (early) }\end{array}$ & $60-110$ mg. $\%$ & +15mm. $\mathrm{Hg}^{*}$ & $+10.6 \mathrm{~cm} . \mathrm{H}_{2} \mathrm{O}$ & $\begin{array}{l}\mathbf{M}-9.6 * \\
\mathbf{R}-1.9 \text { to } 14.3\end{array}$ & $\begin{array}{l}\mathbf{M}-236 \\
\mathbf{R}-60 \text { to }-420\end{array}$ & 5 & 8 \\
\hline $\begin{array}{l}\text { Diethyl ether } \\
\text { (inte) }\end{array}$ & $84-114$ mg. 9 & $-1 \mathrm{~mm}, \mathrm{Hc}$ & $+4.2 \mathrm{~cm} . \mathrm{H}_{2} \mathrm{O}$ & $\begin{array}{l}M-4.9 * \\
R-3.7 \text { to }-7.8\end{array}$ & $\begin{array}{l}M-121 \\
R-60 \text { to }-230\end{array}$ & 5 & 8 \\
\hline $\begin{array}{l}\text { Thiopental- } \\
\text { Nitrous Oidde }\end{array}$ & $\begin{array}{c}0.6-2.5) \\
23-52)\end{array}$ & $-16 \mathrm{~mm}, \mathrm{Hg}$ & $-0.8 \mathrm{~cm} . \mathrm{H}_{2} \mathrm{O}$ & $\begin{array}{l}M+3.0^{*} \\
R-2.5 \text { to }+7.3\end{array}$ & $\begin{array}{l}M+108 \\
R-40 \text { to }+190\end{array}$ & 6 & 16 \\
\hline
\end{tabular}

Denotes afrenticant change $(p<0,05)$ by Fisber t test

* Auscultatory blood preseure doterminations; changes refer to diastollc pressure

Abbreviations: A.P. Arterial pressure, V.P. Venous pressure, P.V. Plasma volume, M. Mean, R. Range.

dation and during anesthesia are summarized in Table II. Each value is an average of the mean of three determinations made at fifteen to twentyfive-minute intervals in each of the patients studied. Values marked with an asterisk represent statistically significant differences from the presedated or pre-anesthetized levels $(p<0.05)$. The changes in plasma volume are calculated sequentially; i.e., the changes calculated after preanesthetic sedation use the pre-sedated values as a baseline, while the changes measured during anesthesia refer to the last values obtained before the induction of anesthesia. All blood volume determinations made in the group of twenty-one subjects reported in Table II employed $\mathrm{Cr}^{51}$ red cell tagging.

Pre-anesthetic sedation: The administration of atropine or scopolamine had no measurable effect on plasma volume or arterial pressure. Addition of morphine to the pre-anesthetic medication was associated with a significant increase in plasma volume. No consistent change in arterial pressure occurred after morphine was given, although usually there was a decrease. The period of observation varied between forty minutes and one hour and fifteen minutes following the intravenous injection of these drugs.

Cyclopropane: The patients receiving cyclopropane were divided into two equal groups on the basis of the mean concentration of cyclopropane observed in blood samples drawn at fifteen-minute intervals during the period of anesthesia. In the lightly-anesthetized group, adequate ventilation was produced by intermittent compression of the breathing bag of the anesthesia machine synchronous with the patient's inspirations. The $\mathrm{pCO}_{2}$ in arterial blood averaged $50.0 \mathrm{~mm} . \mathrm{Hg}$ and $\mathrm{O}_{2}$ saturation 99 per cent. In the deeply-anesthetized group apnea or severely reduced respiratory exchange was produced by the anesthetic agent, and manually controlled positive pressure respiration was used throughout anesthesia. In 
this group the $\mathrm{pCO}_{2}$ was lower (average $28 \mathrm{~mm}$. $\mathrm{Hg}$ : range 18 to $37 \mathrm{~mm}$. $\mathrm{Hg}$ ). Oxygen saturation averaged 98 per cent.

The first group showed an insignificant change in plasma volume and the arterial pressure was not consistently altered by anesthesia. The venous pressure, however, increased in all cases (average $7.9 \mathrm{~cm} . \mathrm{H}_{2} \mathrm{O}$ ). The second group exhibited a significantly reduced plasma volume with consistently increased arterial and venous pressures $\left(+20 \mathrm{~mm}\right.$. $\mathrm{Hg}$ and $+14.2 \mathrm{~cm} . \mathrm{H}_{2} \mathrm{O}$ respectively). The time of these observations ranged between 20 and 73 minutes after the induction of anesthesia; there was no difference, on the average, between the time of observations in the "light" and "deep" groups.

Diethyl ether: Observations on the subjects receiving this anesthetic were divided into two groups-early and late-because most of the patients studied exhibited signs of "excitement" or other undesirable side effects of anesthesia (transient arterial hypertension in four subjects, coughing in one, diminished oxygen saturation of arterial blood in two, and brief struggling in two) during the induction of anesthesia. In the "early" period (17 to 35 minutes after induction) there was a significant decrease in plasma volume, accompanied by consistently increased arterial and venous pressures. The $\mathrm{pCO}_{2}$ averaged $56 \mathrm{~mm}$. $\mathrm{Hg}$, and oxygen saturation 87 per cent. After the establishment of anesthesia with diethyl ether, all values began to revert toward normal. The plasma volume increased progressively, although it remained significantly reduced in observations made as late as 80 minutes after induction. The changes in arterial pressure were completely reversed and those in venous pressure partially so in the "late" period of anesthesia. Oxygen saturation averaged 97 per cent at this time, and $\mathrm{pCO}_{2}$ $57 \mathrm{~mm}$. $\mathrm{Hg}$.

Thiopental-nitrous oxide: In this group a significant increase in plasma volume occurred, accompanied by a consistent decrease in arterial pressure, but there was no consistent change in venous pressure. The observations were made between 15 and 84 minutes following the induction of anesthesia. Most of the change in plasma volume occurred within the first half-hour. The arterial $\mathrm{pCO}_{2}$ averaged $46 \mathrm{~mm}$. $\mathrm{Hg}$ and oxygen saturation 99 per cent.

Effects of surgical operation: Operation had no consistent effect on plasma volume, arterial pressure, or venous pressure. In some instances a decrease in plasma volume occurred coincident with the beginning of operation; this was always accompanied by an increase in arterial pressure, and

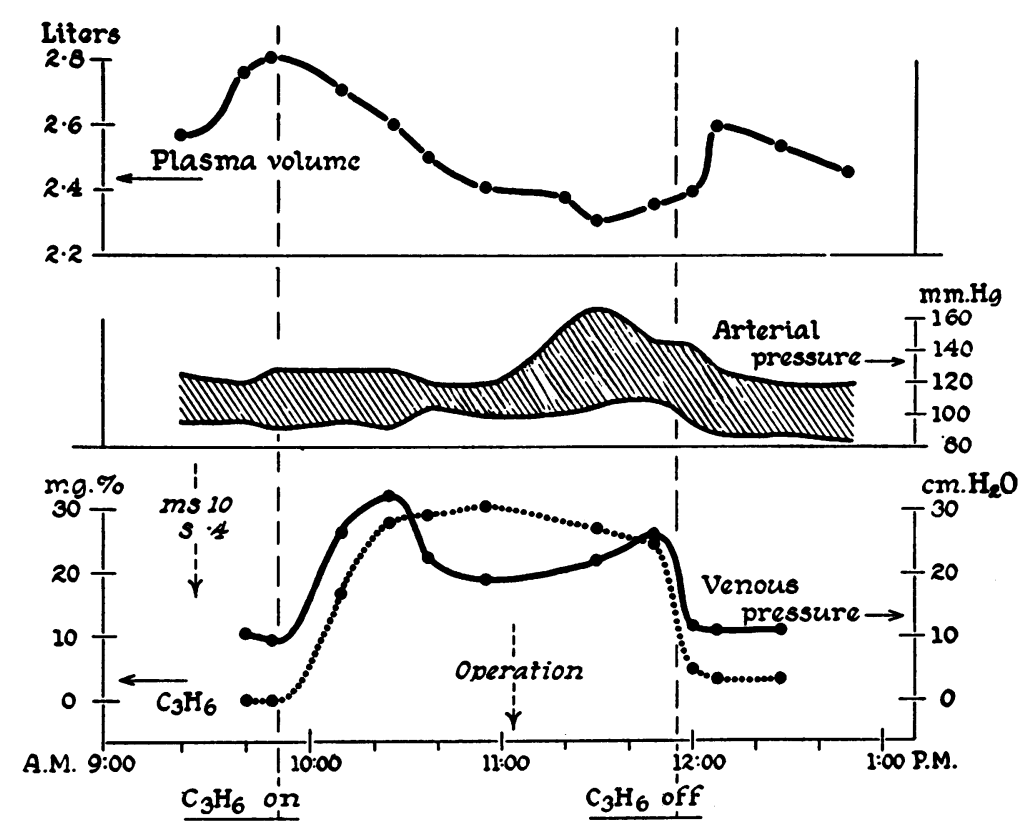

Figure 1 
usually venous pressure increased also. Figure 1 illustrates a typical example.

Recovery from anesthesia: In all subjects the measured values tended to return toward those observed before the induction of anesthesia. However, plasma volume was usually less upon emergence from anesthesia than just before its induction.

\section{DISCUSSION}

The constancy of the relation between counts per minute and the hemoglobin concentration in peripheral blood indicates: 1) complete mixing of tagged and untagged erythrocytes, and 2) lack of an appreciable loss of $\mathrm{Cr}^{51}$ from the cells. The first consideration rules out the possibility that sequestered (i.e., unmixed) red cells are added to the circulation during general anesthesia, but does not imply that the distribution of erythrocytes among capillaries, large blood vessels, and "blood reservoirs" such as the spleen is unaffected by anesthetics. However, the agreement between plasma volume changes estimated from simultaneous measurements of peripheral hematocrit and plasma T-1824 concentration suggests that the whole body-peripheral hematocrit ratio is unaffected by anesthesia, and that the dilatation or contraction of viscera containing a high concentration of erythrocytes is not important in producing blood volume changes during general anesthesia in man.

In contrast to this, general anesthesia in the dog is accompanied by marked changes in the peripheral hematocrit which are prevented or reduced by splenectomy $(4,5,18)$, and plasma volume changes estimated from the hematocrit do not agree with those measured simultaneously by dye dilution. Splenectomy brings the calculations into agreement $(3,5)$.

Apparently the anesthetics studied do not affect the rate of disappearance of $\mathrm{T}-1824$ from the plasma, since estimation of the plasma volume change by hematocrit and dye dilution agree for some time after the induction of anesthesia. The progressive divergence between plasma volume changes calculated by the two methods which begins eighty minutes after the injection of dye may be related to the fact that the rate of dye disappearance from the plasma has been found to diminish abruptly at this time (19).

If changes in systemic arterial and venous pres- sures exert directionally similar effects on capillary hydrostatic pressure, the plasma volume changes observed during anesthesia can be viewed as resulting from accompanying hemodynamic alterations. It is conceivable that a decrease in systemic arterial pressure may accompany an increase in mean capillary hydrostatic pressure, and vice versa; however, it is less likely that capillary pressure can vary oppositely from venous pressure (20). Hence, it is interesting that a significant decrease in plasma volume was observed in the present study only when venous pressure was elevated. Venous pressure changes in the arm may not equal those occurring elsewhere, but in man the intrathoracic venous and right atrial pressures appear to be elevated during cyclopropane and ether anesthesia by an amount similar to the increase in peripheral venous pressure (21-23). A limited number of observations suggests that the intrathoracic venous pressure is slightly reduced during thiopental anesthesia (24), and this again agrees with the change in peripheral venous pressure.

During deep anesthesia with cyclopropane the plasma volume may also be reduced by an increase in the general level of venous pressure resulting from intermittent positive pressure inflation of the lungs, and by an increase in mean arterial pressure. Increased arterial pressure has been noted previously during cyclopropane anesthesia $(21,22)$, but it remains unexplained.

Increased arterial pressure was observed only during the period immediately following the induction of ether anesthesia, and it occurred in several instances during demonstrable asphyxia. Venous pressure remained elevated during the "late" period of ether anesthesia but the elevation was less than half that observed shortly after induction. It is therefore possible that the decrease of plasma volume persisting into the later period of ether anesthesia resulted from an incomplete reversal of earlier changes.

The plasma volume changes during thiopental anesthesia were in the direction expected from the alterations in arterial and venous pressure. Increased plasma volume following the administration of morphine occurred in the absence of any consistent change in arterial pressure, although a decrease was noted in most instances. 
The clinical significance of these observations is difficult to determine. In man the extracellular fluid volume remains essentially constant during anesthesia with cyclopropane, ether, or thiopental (25), so that one way of viewing the present results is to suppose that thiopental anesthesia and morphine result in partial depletion of the extravascular extracellular fluid volume, while cyclopropane and ether do not. Cyclopropane or ether might therefore be better tolerated by patients with a depleted extracellular fluid volume than thiopental. In support of this view it has been found that pentobarbital, whose hemodynamic effects resemble those of thiopental, reduces the rate of restoration of the plasma volume after hemorrhage in dogs, cats, and rabbits (26).

\section{SUMMARY AND CONCLUSIONS}

1. General anesthesia in man is accompanied by changes in the plasma volume which are opposite in direction to simultaneous changes in arterial and venous pressures.

2. The contraction or dilatation of viscera containing a high erythrocyte concentration is probably not important in producing changes in the circulating blood volume during general anesthesia in man.

\section{ACKNOWLEDGMENTS}

The authors wish to thank Dr. Timothy Talbot for a critical review of the manuscript. The technical assistance of Margaret P. Fritz and Mary L. Price is also gratefully acknowledged.

\section{REFERENCES}

1. Gibson, J. G., 2nd, and Branch, D. C., Blood volume changes during surgical procedures. Surg., Gynec. \& Obst., 1937, 65, 741.

2. Stewart, J. D., and Rourke, G. M., Changes in blood and interstitial fluid resulting from surgical operation and ether anesthesia. J. Clin. Invest., 1938, 17, 413.

3. Bonnycastle, D. D., The effect of some anaesthetic agents on the volume of body fluid. J. Pharmacol. \& Exper. Therap., 1942, 75, 18.

4. Bollman, J. L., Svirbely, J. L., and Mann, F. C., Blood concentration influenced by ether and Amytal anesthesia. Surgery, 1938, 4, 881.

5. McAllister, F. F., The effect of ether anesthesia on the volume of plasma and extracellular fluid. Am. J. Physiol., 1938, 124, 391.
6. Hausner, E., Essex, H. E., and Mann, F. C., Roentgenologic observations of the spleen of the dog under ether, sodium Amytal, pentobarbital sodium and pentothal sodium anesthesia. Am. J. Physiol., 1938, 121, 387.

7. Gray, S. J., and Sterling, K., The tagging of red cells and plasma proteins with radioactive chromium. J. Clin. Invest., 1950, 29, 1604.

8. Vazquez, O. N., Newerly, K., Yalow, R. S., and Berson, S. A., Determination of trapped plasma in the centrifuged erythrocyte volume of normal human blood with radioiodinated $\left(\mathrm{I}^{121}\right)$ human serum albumin and radiosodium $\left(\mathrm{Na}^{24}\right)$. J. Lab. \& Clin. Med., 1952, 39, 595.

9. Rosenthal, T. B., Effect of temperature on $\mathrm{pH}$ of blood and plasma. J. Biol. Chem., 1948, 173, 25.

10. Orcutt, F. S., and Waters, R. M., A method for the determination of cyclopropane, ethylene, and nitrous oxide in blood with van Slyke-Neill manometric apparatus. J. Biol. Chem., 1937, 117, 509.

11. Shaffer, P. A., and Ronzoni, E., Ether anesthesia. I. The determination of ethyl ether in air and in blood, and its distribution ratio between blood and air. J. Biol. Chem., 1923, 57, 741.

12. Brodie, B. B., Mark, L. M., Papper, E. M., Lief, P. A., Bernstein, E., and Rovenstine, E. A., The fate of thiopental in man and a method for its estimation in biological material. J. Pharmacol. \& Exper. Therap., 1950, 98, 85.

13. van Slyke, D. D., and Sendroy, J., Jr., Studies of gas and electrolyte equilibria in blood. XV. Line charts for graphic calculations by the HendersonHasselbalch equation, and for calculating plasma carbon dioxide content from whole blood content. J. Biol. Chem., 1928, 79, 781.

14. Austin, J. H., A note on the estimation of carbon dioxide in serum in the presence of ether by the van Slyke method. J. Biol. Chem., 1924, 61, 345.

15. Gibson, J. G., 2nd, Peacock, W. C., Seligman, A. M., and Sack, T., Circulating red cell volume measured simultaneously by the radioactive iron and dye methods. J. Clin. Invest., 1946, 25, 838.

16. Chaplin, H., Jr., Mollison, P. L., and Vetter, H., The body/venous hematocrit ratio: Its constancy over a wide hematocrit range. J. Clin. Invest., 1953, 32, 1309.

17. Strumia, M. M., Taylor, L., Sample, A. B., Colwell, L. S., and Dugan, A., Uses and limitations of survival studies of erythrocytes tagged with $\mathrm{Cr}^{\mathrm{si}}$. Blood, 1955, 10, 429.

18. Pender, J. W., and Lundy, J. S., Changes of concentration of hemoglobin during anesthesia in man and animals. Anesthesiology, 1944, 5, 163.

19. Overbey, D. T., Moore, J. C., Shadle, O. W., and Lawson, H. C., Rate of disappearance of dye T-1824 from arterial blood. Am. J. Physiol., 1947, 151, 290.

20. Pappenheimer, J. R., and Soto-Rivera, A., Effective osmotic pressure of the plasma proteins and other quantities associated with the capillary circula- 
tion in the hind limbs of cats and dogs. Am. J. Physiol., 1948, 152, 471.

21. Price, H. L., King, B. D., Elder, J. D., Libien, B. H., and Dripps, R. D., Circulatory effects of raised airway pressure during cyclopropane anesthesia in man. J. Clin. Invest., 1951, 30, 1243.

22. Price, H. L., Conner, E. H., and Dripps, R. D., Concerning the increase in central venous and arterial blood pressures during cyclopropane anesthesia in man. Anesthesiology, 1953, 14, 1.

23. Fletcher, G., and Pender, J. W., Hemodynamic effects of ether anesthesia and surgery in man. Federation Proc., 1954, 13, 354.
24. Price, H. L., Conner, E. H., Elder, J. D., and Dripps, R. D., Effect of sodium thiopental on circulatory response to positive pressure inflation of lungs. J. Applied Physiol., 1952, 4, 629.

25. Crawford, E. J., and Gaudino, M., Changes in extracellular fluid volume, renal function, and electrolyte excretion induced by intravenous saline solution and by short periods of anesthesia. Anesthesiology, 1952, 13, 374.

26. Courtice, F. C., and Gunton, R. W., Effect of Nembutal anesthesia on restoration of plasma volume after hemorrhage in dogs, cats, and rabbits. J. Physiol., 1949, 108, 418. 